DOI: https://doi.org/10.24127/ajpm.v10i1.3546

\title{
GAMES PEMBELAJARAN BERBASIS ANDROID UNTUK MENDUKUNG CURIOSITY ANAK DALAM MENGENALKAN MATEMATIKA AWAL
}

\author{
Chika Rahayu $^{1^{*}}$, Ratu Ilma Indra Putri ${ }^{2 *}$ Zulkardi $^{3}$, Yusuf Hartono ${ }^{4}$ \\ ${ }^{1 *}, 2^{*}, 3,4$ Program Doktor Pendidikan Matematika, Universitas Sriwijaya, Palembang, \\ Indonesia \\ ${ }^{*}$ Corresponding author. Universitas Sriwijaya, Palembang, Indonesia \\ E-mail: $\quad$ chikarahayu80@gmail.com ${ }^{1 *}$ \\ ratu.ilma@yahoo.com $^{2 *}$ \\ zulkardi@gmail.com $^{3)}$ \\ y_hartono@yahoo.com ${ }^{4)}$
}

Received 09 February 2021; Received in revised form 09 March 2021; Accepted 29 March 2021

\begin{abstract}
Abstrak
Pendesainan ini bertujuan untuk menghasilkan games pembelajaran berasis android untuk mendukung curiosity anak usia dini dalam mengenalkan matematika awal yang layak dan praktis serta memiliki efek potensial untuk mendukung curiosity anak dalam mengenalkan matematika awal. Penelitian ini menggunakan development research yang terdiri dari perencanaan, tahap pengembangan, dan evaluasi. Penelitian ini melibatkan validator sebagai ahli media serta ahli materi lainnya. Subjek penelitian adalah anak usia dini sebanyak 18 anak usia dini di TK Dharma Wanita Kota Pagaralam. Pada artikel ini akan menceritakan tentang tahapan evaluasi pendesainan games pembelajran berbasis android. Hasil dari penelitian ini menunjukan bahwa games pembelajaran berbasis android yang dikembangkan dinyatakan valid, layak digunakan dan praktis oleh para ahli yang diuji dari aspek media, aspek materi dan praktisi. Serta memiliki efek potensial untuk mendukung curiosity anak dalam mengenal matematika awal. Penelitian ini memberikan kontribusi dalam pembelajaran bagi anak usia dini dengan menggunakan mini games untuk mendukung rasa ingin tahu anak dalam pembelajaran matematika serta menambah referensi pembelajaran bagi guru usia dini dalam menggunakan teknologi pada proses pembelajaran.
\end{abstract}

Kata kunci: anak usia dini; android; curiosity; games pembelajaran; matematika awal.

\begin{abstract}
The aim of this design was to produce learning games based android for supporting early childhood's curiosity in introducing initial mathematic which were proper, practical, and had a potential effect to support early childood's curiosity for introducing initial mathematic. This research used development research with planning, developing, and evaluating stage. This research involved validator as media expert and other material experts. The subject of this research were 18 early childhood children in TK Dharma Wanita Pagar Alam. This article would explain about the evaluation stages of android based learning games. The result of this study showed that android based learning games developed by the researcher were valid, proper to be used, and practical by experts which were tested from media aspect, material aspect, and practicioners. Moreover, it had a potential effect to support children's curiosity in recognizing mathematics.
\end{abstract}

Keywords: android; curiosity; early childhood; early mathemathics; learning games.

This is an open access article under the Creative Commons Attribution 4.0 International License

\section{PENDAHULUAN}

Pengenalan awal matematika terhadap anak usia dini menjadi perhatian berbagai kalangan, berbagai penelitian mengungkapkan pentingnya keberhasilan matematika sejak dini adalah indikator suksesnya anak untuk melangkah ke jenjang selanjutnya. 
Pengenalan matematika pada anak usia dini mencangkup berbagai konten seperti bilangan dan operasi sederhana, geometri, aljabar, pola dan pengukuran (Bozick et al., 2017; Clements \& Sarama, 2007; Musrikah, 2017). Memberikan rangsangan anak untuk mengenal, memahami dan menggunakan matematika awal sejak dini memberikan pengaruh yang postif pada perkembangan curiosity, kepercayaan dirinya, imajinasi, kreatifitasnya, fleksibilitas serta daya ciptanya yang dapat ber kontribusi pada kesuksesan masa depan mereka di dalam dan di luar sekolah (Clements \& Group, 2004) Penelitian terdahulu mengatakan bahwa masih banyak anak usia dini yang belum berkesempatan menjalani pembelajaran matematika secara substansial (Clements \& Sarama, 2011; Perry \& Dockett, 2015).

Pembelajaran matematika berkaitan dengan konsep abstrak yang tersusun melalui penalaran, namun matematika di usia dini berkaitan dengan kegiatan pembelajaran tentang konsep matematika melalui aktivitas bermain yang dapat dihubungkan dalam kehidupan nyata. Pengenalan pengetahuan awal matematika dapat dikenalkan pada anak sejak usia dini (26 tahun). Konsep matematika pada anak usia dini ditemukan setiap hari melalui pengalaman bermainnya. Contohnya membagikan makanan pada anggota keluarga, menuangkan air ke wadah plastik, mengikuti pola tepuk tangan dan nyanyian mengenal angka. Pendekatan pembelajaran yang dapat dikaitkan dengan konsep seperti ini adalah PMRI yaitu Pendidikan Matematika Realistik Indonesia yang memulai pembelajaran dari pengelaman dan kegiatan sehari-hari.

Teori Piaget di dalam (Laorenco, 2015) menghubungkan teori kognitif dengan curiosity teori kognitif merupakan tingkah laku yang secara tiba-tiba dengan bermacam-macam stuktur psikologi, unit yang tersusun atau pola dari pikiran yang dipengaruhi dari bagaimana anak menafsirkan informasi yang diberikan. Piaget menyatakan meskipun anak-anak mempunyai kemampuan kognitif yang sama tapi mereka mempunyai nilai yang berbeda. Sependapat dengan ini (De Lange, 2019; Trundle et al., 2013) mengemukakan bahwa anak-anak mempunyai curiosity dan banyak pertanyaan, dimana hal ini merupakan starting point untuk mengeksplor dunianya. Selanjutnya penelitian sebelumnya (Kashdan et al., 2018; Mustari, 2011; Pluck \& Johnson, 2011; Raharja et al., 2018; Sarilawati, 2012) mengemukakan bahwa curiosity merupakan pondasi dasar atau sumber dari motivasi dalam mencari informasi baik itu dalam proses pembelajaran dan potensi besar dalam memecahkan persoalan dalam kehidupan. Lebih spesifik lagi curiosity merupakan faktor yang membantu dalam proses pembelajaran agar siswa aktif dan sebagai faktor untuk mengembangkan diri (Raharja et al., 2018)

Permasalahan yang sangat krusial adalah ketidaksiapan pembelajaran daring selama masa covid 19. Guru harus memiliki kemampuan menyiapkan kegiatan pembelajaran dalam situasi apapun termasuk menjaga curiosity anak untuk belajar termasuk pada ranah kognitif karena kesiapan guru dapat menetukan keberhasilan suatu program pembelajaran di sekolah dan dapat meningkatkan belajar anak (Korth et al., 2009; Sum \& Taran, 2020). Keterbatasan kemampuan guru dalam membuat inovasi media pembelajaran saat masa pandemi, hal ini dikarenakan berbagai faktor, masih 
kurangnya sarana dan prasarana sekolah yang belum merata ke seluruh daerah dan pemahaman penggunaan teknologi hanya sebagai pembuatan administrasi sekolah (Rahayu et al., 2019a).

Saat ini anak usia dini tumbuh di dunia yang semakin dibentuk oleh Teknologi (Chusna, 2017; Mashrah, 2017; Siraj-Blatchford, John; Whitebread, 2003), sedari balita, anakanak sudah mengenal gadget dan menjadi kebutuhan ketika mereka memasuki usia sekolah dasar. Penggunaan teknologi dalam pembelajaran bagi anak usia dini sebagai media pembelajaran seperti komputer, ipad, handphone dan benda teknologi lainnya menjadi perdebatan hangat. Perdebatan ini mengenai pendapat para ahli tentang efek negatif yang ditimbulkan dari penggunaan komputer dan teknologi lainnya pada ranah kognitif khususnya (Chonchaiya \& Pruksananonda, 2008; Nabawy et al., 2016). Namun penelitian lain membuktikan bahwa penggunaan ICT saja tidak cukup untuk mempengaruhi dalam memaksimalkan pembelajaran dan perkembangan anak, diperlukanya media ICT yang efektif untuk pembelajaran PAUD, dalam hal ini harus ada keterlibatan aktif antara guru, anak dan orang tua, serta diberikan kesempatan umpan balik positif kepada anak dan pembelajaran teknologi dapat dihubungkan dengan kehidupan seharihari (Kumari, 2016). Media belajar yang dapat digunakan untuk AUD adalah segala sesuatu yang berupa bahan (software) dan alat (hardware) untuk bermain sambil belajar yang membuat anak-anak usia dini mampu memperoleh pengetahuan, keterampilan dan sikap (Latif, 2013). Sebaiknya memilih dan memilah aplikasi smartphone yang mengutamakan pendidikan, baik untuk mengembangkan kemampuan kognitif ataupun kemampuan lainya yang berdampak positif bagi perkembangan anak. Selanjutnya (Clements et al., 2004; Dwyer, 2007; Fisher et al., 2012; Lee, 2009; Suhana, 2018) menyatakan ICT berperan besar untuk pembelajaran usia PAUD dengan aplikasi yang mempunyai keutamaan mendukung pada tujuan kurikulum pendidikan serta kesesuain bahasa dan aspek perkembangan anak yang tepat. Terkait dengan pembelajaran matematika sendiri, permasalahan menimbulkan makin sulitnya anak mendapatkan kesempatan belajar, bermain serta mengembangkan kemampuannya dalam pengenalan matematika. Oleh karena itu perlu untuk games pembelajaran berbasis android dalam pembelajaran matematika awal. Penelitian ini bertujuan mengembangkan games pembelajaran berbasis android dengan pendekatan PMRI. Hal ini berhubungan dengan pembelajaran matematika awal pada usia dini merupakan masa pembelajaran pengenalan matematika yang dapat dikaitkan dengan pengalaman anak sehari-hari. Games pembelajaran yang dikembangkan ditujukan untuk mendukung curiosity anak dalam pembelajaran matematika awal.

\section{METODE PENELITIAN}

Penelitian menggunakan metode development research, metode ini betujuan menghasilkan sebuah produk dan menguji keefektifan. Model Rowntree digunakan pada penelitian pengembangan memiliki tiga tahapan yaitu tahap perencanaan, tahap pengembangan dan tahap evaluasi.

Pada tahapan perencanaan, melakukan survey dengan wawancara beberapa guru serta orang tua murid untuk mengetahui kebutuhan di 
lapangan dan mencari informasi kendala yang dihadapi dan mencari referensi tambahan yang diperlukan. Pada tahap pengembangan, tahapan ini mengembangkan media dengan mengumpulkan data materi yang akan dikembangkan dari buku dan contoh aplikasi. Selanjutkan mendesain games pembelajaran dengan sesuai materi yang akan dikembangkan. Tahapan selanjutnya evaluasi, mengumpulkan data untuk melihat keefektifan suatu produk di lapangan, dimana kefektifan suatu produk di evaluasi dengan melakukan evaluasi formatif yang disebut dengan formative study yang terdiri dari beberapa tahapan (Tessmer, 1993) yaitu Self Evaluation, expert reviews, One-To-One Evaluations, Small Group Evaluations, dan Field Trials. Penjelasan tiap tahapan dijabarkan pada bagian hasil dan pembahasan artikel ini dan untuk melihat efek potensial games pembelajaran dilihat dari kualitas sikap curiosity anak menggunakan lembar observasi. Penelitian ini menggunakan Ahli dan praktisi sesuai bidang untuk menyatakan bahwa games pembelajaran tersebut efektif dan untuk memberikan hasil sesuai yang diharapkan secara operasional games pembelajaran tersebut di uji coba dan di nilai dengan lembar observasi. Artikel ini akan membahas khusus tentang tahapan mendesain games pembelajaran berbasis android yang valid dan praktis untuk mendukung curiosity anak dalam pembelajaran matematika awal.

Subjek dalam penelitian ini adalah 18 anak usia dini TK Dharma Wanita Kota Pagaralam. Instrumen yang digunakan untuk mengumpulkan data terdiri dari lembar validasi expert, wawancara, observasi yang didokumentasikan terdiri atas video proses pembelajaran serta lembar observasi untuk mengetahui efek potensial sikap curiosity dalam menggunakan games pembelajaran untuk mengenal matematika awal.

Pengumpulan data melalui lembar validasi yang berupa catatan para ahli dalam memvalidasi games pembelajaran berbasis android yang dikembangkan dari segi media, materi serta konten. Data ini berisikan penilaian berupa cheklis serta komentar para ahli dan perbaikan unstuk merevisi produk. Lembar validasi expert dihitung dengan rumus Skala Likert dengan kategori : $5=$ Sangat Setuju, $4=$ Setuju, $3=$ Netral, 2 = Tidak Setuju, 1 = Sangat Tidak Setuju. Kemudian data dianalisis dengan menghitung rata-rata skor dengan rumus (1):

$$
x=\frac{\sum x}{\mathrm{~N}}
$$

Keterangan:

$$
\begin{array}{ll}
x & =\text { nilai rata-rata } \\
\sum x & =\text { jumlah nilai } \\
N & =\text { jumlah subjek }
\end{array}
$$

Hasil perhitungan rata-rata skor kemudian di kategorikan berdasarkan kriteria seperti pada Tabel 1.

Tabel 1. Konversi kategori pedoman skor.

\begin{tabular}{cl}
\hline Rumus & \multicolumn{1}{c}{ Kategori } \\
\hline $4,21-5,00$ & Sangat Layak \\
$3,41-4,20$ & Layak \\
$2,61-3,40$ & Kurang layak \\
$1,81-2,60$ & Tidak layak \\
$0,00-1,80$ & Sangat tidak layak \\
\hline
\end{tabular}

(Sukardjo, 2012)

Pengumpulan data berikutnya sengan Wawancara dilakukan untuk pengumpulan data. Hal ini dilakukan secara face to face dan jenisnya adalah wawancara tak berstruktur yang bertujuan untuk mengetahui hambatan 
yang dihadapi serta kesukaan anak pada produk. Observasi dilakukan untuk melihat kegiatan proses pembelajaran anak yang direkam saat berlangsungnya pembelajaran. Hal ini digunakan untuk mengetahui keefektivan games pembelajaran yang dikembangkan.

Lembar observasi berupa pengamatan indikator sikap ketika terjadinya suatu kegiatan selama proses menggunakan games pembelajaran berbasis android dan untuk mengetahui curiosity anak dalam pengenalan matematika, lembar observasi dihitung dengan persentase skor lembar observasi berdasarkan indikator sikap curiosity anak, explore, discover, imajinasi dan bertanya.

\section{HASIL DAN PEMBAHASAN}

Artikel ini membahas tentang tahapan evaluasi pengembangan games pembelajaran berbasis android untuk mendukung curiosity anak dalam pembelajaran matematika awal. Penelitian ini dilaksanakan pada bulan Februari sampai dengan bulan November 2020 dengan tema budayaku, subtema negaraku dan makanan khas daerah. Menurut Tessmer Tahapan utama dalam formative study adalah evauasi diri, expert reviews, One-ToOne Evaluations, Small Group Evaluations, dan Field Trials. Penjelasan tahapan sebagai berikut.

\section{a. Evaluasi Diri}

Tahap ini menganalisa games pembelajaran yang telah dikembangkan, tujuan dari tahap ini adalah untuk merevisi produk. Evaluasi yang dilakukan meliputi proses desain pembelajaran, materi yang digunakan serta media teknologi yang dapat dikatakan layak untuk dapat dilanjutkan ketahap berikutnya. Hasil dari evaluasi diri yang ditunjukkan pada Tabel 3.

Tabel. 3 Hasil evaluasi diri.

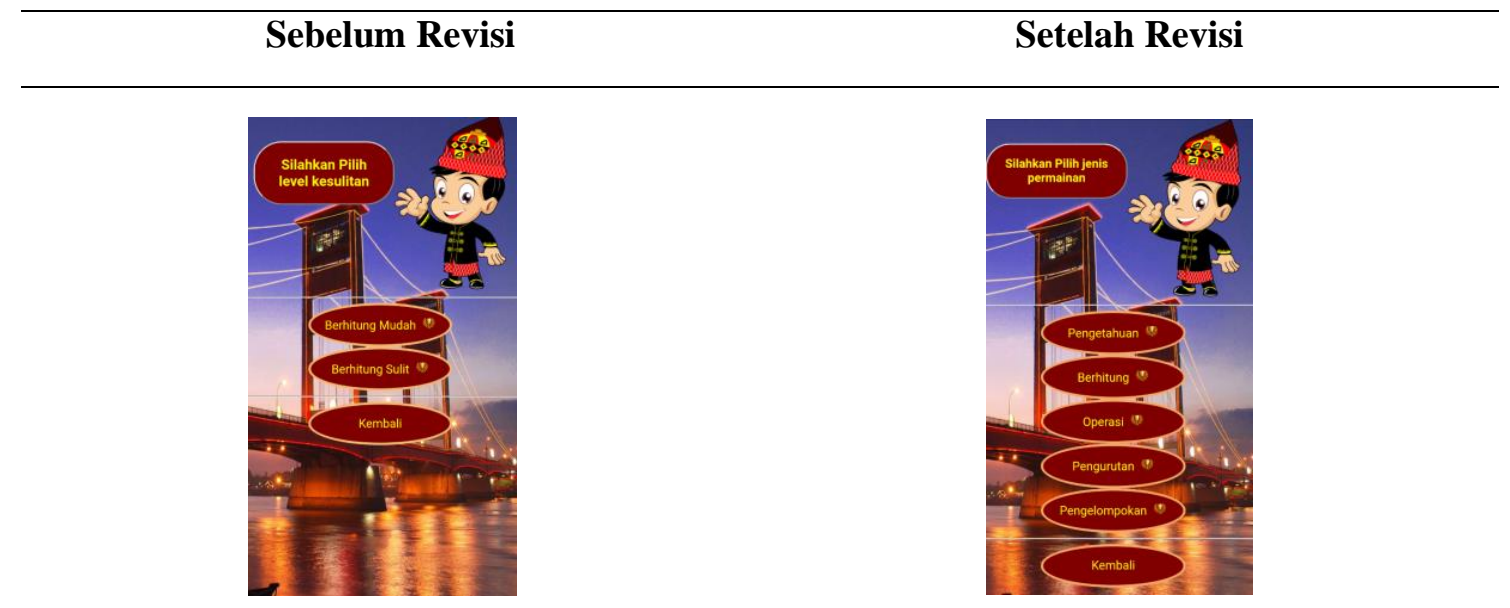

Tidak ada suara anak sebagai petunjuk mengerjakan permainan dan jenis permainanya masih sedikit
Menambah suara anak sebagai petunjuk mengerjakan persoalan yang ada di permainan, jenis permainan nya diperbanyak sesuai dengan KD yang ada 
DOI: https://doi.org/10.24127/ajpm.v10i1.3546

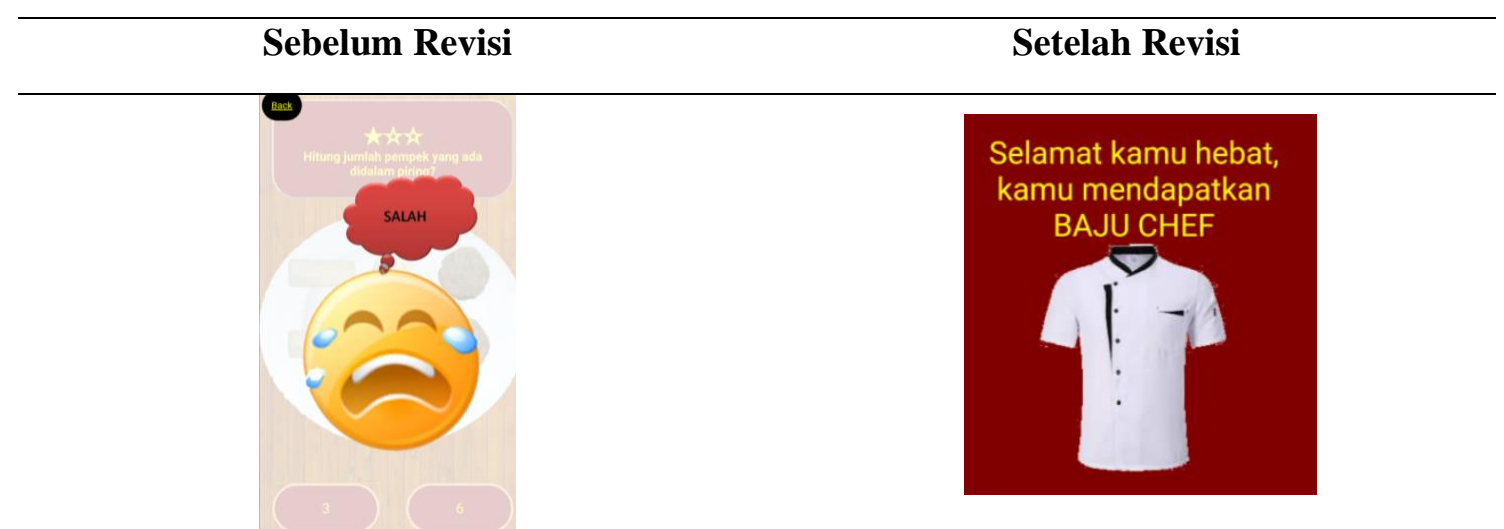

Emoticon yang muncul ketika anak menjawab tidak tepat, anak menjadi tidak bersemangat.

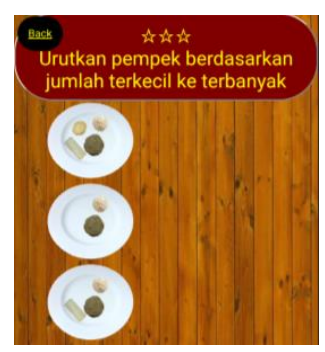

Tidak memunculkan gambar angka di dalam piring

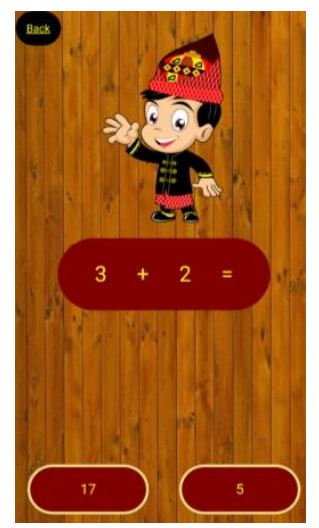

Berupa angka saja dan tidak ada cara petunjuk

Games pembelajaran yang telah diproses pada tahap evaluasi diri terdapat pengembangan setelah direvisi yang disebut dengan prototype pertama. Tahapan berikutnya adalah tahapan jika anak menjawab salah, muncul suara anak "kamu kurang tepat, coba lagi" dan anak mendapat apresiasi dengan mendapatkan hadiah, anak menjadi bersemangat untuk mencoba lagi.

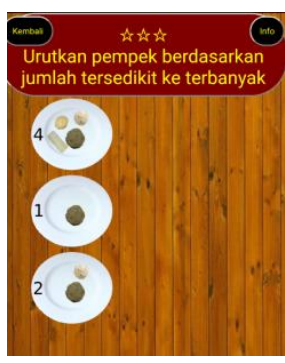

Memunculkan gambar angka berdasarkan jumlah benda di dalam piring

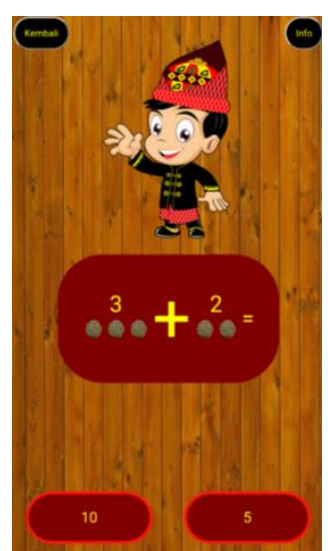

Menampilkan gambar berdasarkan angkanya serta petunjuk cara mengerjakannya

expert review dan one two one evaluation

\section{b. Expert Review}

Produk yang telah melewati tahapan evaluasi diri yaitu prototype pertama dilanjutkan ke tahapan expert 
review, expert riview pada tahapan ini meliputi ahli media bidang pendidikan yaitu Dr.rer.nat. Adi Nur Cahyono, S.Pd., M.Pd, ahli materi yaitu Dr. Sri Sularti Dewanti Handayani, M. Pd dan ahli praktisi dalam hal ini para guru yang terjun langsung ke lapangan yaitu Ibu Dewi Erlita,S.Pd, Ibu Pia Oktari, S.Pd dan Eli Fitriana, Spd.I.

Berikut saran serta tanggapan validator tentang produk games pembelajaran :

\section{1) Ahli Media}

Ahli media telah memvalidasi produk dan menyatakan bahwa games yang di desain sudah relevan dan materi sudah tepat untuk anak usia dini, sebagai masukan perlunya tambahan suara musik yang menarik sebagai media pendengaran selain suara ikon pada games dan perbaikan pada beberapa tombol untuk memudahkan anak menjalakan permainan. Dari tahapan yang telah dilakukan dapat disimpulkan produk telah valid dan praktis, hal ini telah di review oleh para expert dalam hal ini review ahli media Dr.rer.nat. Adi Nur Cahyono, S.Pd., M.Pd dengan rata-rata hasil validasi medi 4,6 dengan rincian yang ditunjukkan pada Tabel 4 .

Tabel 4. Hasil validasi ahli media

\begin{tabular}{|c|c|c|c|}
\hline $\begin{array}{c}\text { Aspek } \\
\text { yang di } \\
\text { nilai }\end{array}$ & $\begin{array}{c}\text { Jumlah } \\
\text { nilai }\end{array}$ & $\begin{array}{l}\text { Rata- } \\
\text { rata } \\
\text { nilai }\end{array}$ & Kategori \\
\hline $\begin{array}{l}\text { Perangkat } \\
\text { lunak }\end{array}$ & 58 & 4,83 & $\begin{array}{l}\text { Sangat } \\
\text { Layak }\end{array}$ \\
\hline $\begin{array}{c}\text { Komunikasi } \\
\text { visual }\end{array}$ & 54 & 4,5 & $\begin{array}{l}\text { Sangat } \\
\text { Layak }\end{array}$ \\
\hline Total & 112 & 4,66 & $\begin{array}{l}\text { Sangat } \\
\text { Layak }\end{array}$ \\
\hline
\end{tabular}

Menurut (Sukardjo, 2012) mengenai kriteria kelayakan media yang dikembangkan, dengan kreteria $\mathrm{X}>4,2$ kategori sangat layak. Maka dapat disimpulkan bahwa media yang dikembangkan memenuhi kriteria valid sehingga layak untuk digunakan.

\section{2) Ahli Materi}

Hasil expert review dari ahli materi yaitu Games ini bisa diterima, bagus dan menarik, mampu memotivasi anak usia dini dalam belajar matematika permulaan dan sesuai dengan (STPPA) Standar Tingkat Pencapain Perkembangan Anak usia 4-6 tahun. Games ini sudah bisa diterapkan pada anak usia dini namun masih perlu perbaikan pada bagian games yang belum memiliki suara agar diberikan suara serta tambahkan konten yang dapat berkaitan pada tematik. Hasil dari expert review oleh Dr. Sri Sularti Dewanti Handayani, M. Pd dan Kurnia Dewi, M. Pd, dapat dilihat pada Tabel 5 .

Tabel.5 Hasil validasi ahli materi

\begin{tabular}{|c|c|c|c|}
\hline $\begin{array}{c}\text { Aspek yang } \\
\text { dinilai }\end{array}$ & $\begin{array}{c}\text { Jumlah } \\
\text { nilai }\end{array}$ & $\begin{array}{l}\text { Rata } \\
\text {-rata } \\
\text { nilai }\end{array}$ & Kategori \\
\hline Aspek Soal & 64 & 4,5 & $\begin{array}{l}\text { Sangat } \\
\text { Layak }\end{array}$ \\
\hline $\begin{array}{c}\text { Aspek } \\
\text { Bahasa }\end{array}$ & 20 & 5 & $\begin{array}{l}\text { Sangat } \\
\text { Layak }\end{array}$ \\
\hline $\begin{array}{c}\text { Aspek } \\
\text { keterlaksa- } \\
\text { naan }\end{array}$ & 46 & 4,6 & $\begin{array}{l}\text { Sangat } \\
\text { layak }\end{array}$ \\
\hline Total & 130 & 4,7 & $\begin{array}{l}\text { Sangat } \\
\text { layak }\end{array}$ \\
\hline
\end{tabular}

Berdasarkan hasil seperti yang disajikan pada Tabel 5, dapat disimpulkan bahwa materi yang disajikan di dalam pembuatan game sangat layak untuk digunakan kelapangan. Hanya perlu sedikit revisi pada suara dan menambahkan materi lainya yang berhubungan dengan tematik.

3) Ahli Praktisi

Pelaksanaan expert review ahli praktisi dilakukan oleh guru yang berpengalaman mengajar di kelas, hasil 
DOI: https://doi.org/10.24127/ajpm.v10i1.3546

dari ahli praktisi yaitu games pembelajaran yang telah di buat memudahkan praktisi dalam memberikan materi pembelajaran dan telah sesuai dengan tema pada PAUD, tetapi diperlukan penambahan perencanaan pelaksana pembelajaran yang disesuaikan dengan alat dan bahan. Para praktisi Ibu Dewi Erlita,S.Pd, Ibu Pia Oktari, S.Pd dan Ibu Eli Fitriana, S.Pd I. Lembar validasi praktisi pada tahap uji coba memiliki hasil yang ditunjukkan pada Tabel 6 .

Tabel 6. Hasil validasi praktisi

\begin{tabular}{|c|c|c|c|}
\hline $\begin{array}{c}\text { Aspek yang } \\
\text { diamati }\end{array}$ & $\begin{array}{c}\text { Jumlah } \\
\text { nilai }\end{array}$ & $\begin{array}{c}\text { Rata- } \\
\text { rata } \\
\text { nilai }\end{array}$ & Keterangan \\
\hline $\begin{array}{l}\text { Perangkat } \\
\text { lunak }\end{array}$ & 56 & 4,6 & $\begin{array}{l}\text { Sangat } \\
\text { Layak }\end{array}$ \\
\hline $\begin{array}{l}\text { Desain } \\
\text { Pembelajaran }\end{array}$ & 90 & 4,5 & $\begin{array}{l}\text { Sangat } \\
\text { Layak }\end{array}$ \\
\hline $\begin{array}{l}\text { Komunikasi } \\
\text { Visual }\end{array}$ & 74 & 4,6 & $\begin{array}{l}\text { Sangat } \\
\text { Layak }\end{array}$ \\
\hline Total & 220 & 4,56 & $\begin{array}{l}\text { Sangat } \\
\text { Layak }\end{array}$ \\
\hline
\end{tabular}

Dapat disimpulkan bahwa produk yang dikembangkan sangat layak dalam pendesainan pembelajaran dan termasuk dalam kategori praktis

\section{c. Evaluasi satu-satu (One- to- One Evaluation)}

Games pembelajaran yang telah di revisi pada prototype pertama di evaluasi pada tahap one-to-one evaluation. Tahapan ini dilakukan pada 3 orang anak TK Dharma Wanita Kota Pagaralam yang dipilih dengan kemampuan berbeda, yaitu tinggi, sedang dan rendah.

Kelas uji coba terlebih dahulu diberikan pembelajaran matematika awal menggunakan android yang telah di desain. Pelaksanaan pembelajaran awal dengan menggunakan produk android yang telah dibuat di kelas uji coba dapat dilihat pada Gambar 1.

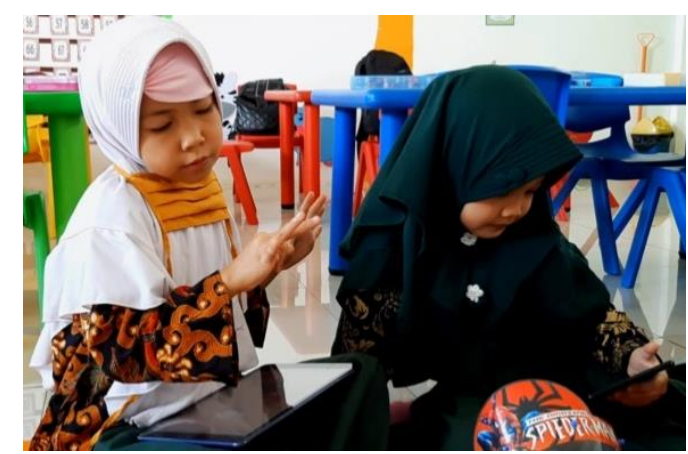

Gambar 1. Anak mengerjakan games pembelajaran pada kelas ujicoba one-to-one evaluation

Pada tahap ini anak diberikan kesempatan untuk belajar matematika awal menggunakan android dengan bermain games edukasi pempek, dimana pempek sebagai konteks awal dalam mengenalkan matematika awal dengan tema budayaku. Penelitian ini juga mewawancarai anak untuk mengetahui tanggapan anak tentang kelebihan dan kekurangan dalam pengembangan media. Anak juga memberikan tanggapan berupa komentar di video wawancara tentang hambatan dalam mengerjakan serta hal yang paling disenangi pada games pembelajaran berserta alasannya. Hal ini penting dilakukan sebagai acuan dalam merevisi produk. Dari produk yang telah di revisi sampai pada tahapan ini, maka produk prototype pertama menjadi proptype ke dua yang akan digunakan pada tahapan small group untuk di evaluasi (small group evaluation).

\section{d. Small group evaluation}

Tahapan selanjutnya adalah mengujicobakan games pembelajaran pada kelas small group yang terdiri dari 5 (lima) anak di kelas B 1. Pada tahapan ini anak diberikan prototye ke dua yaitu games pembelajaran menggunakan android yang telah direvisi berdasarkan 
saran dari expert review dan tahapan one-to-one evaluation. Ke lima anak ini juga diwawancarai diminta komentar tanggapannya tentang hambatan serta hal yang paling mereka senangi pada games pembelajaran. Proses pembelajaran yang berlangsung pada tahapan ini serta komentar tanggapan dari anak yang telah direkam menggunakan kamera dua arah adalah acuan untuk merevisi dalam mengembangan games pembelajaran ini. Setelah prototype ke dua ini direvisi maka dapat disimpulkan produk yang telah jadi disebut dengan prototype ke tiga yang akan diujicobakan pada tahap selanjutnya. Dimana tahapan ini menghasilkan revisi dalam penggunaan tombol pada proses penggunaan games yang lebih praktis dalam menyelesaikan soal, hasil wawancara tahap ini menghasilkan bahwa anak antusias dalam pembelajaran permainan android sebagai pengenalan matematika awal, adanya permainan yang terlalu monoton dalam waktu pengerjaan membuat anak tidak konsisten untuk fokus sehingga perunya revisi mendesain permainan lebih atraktif dan waktu yang singkat, hal ini didukung oleh karena karakteristik anak usia dini yang mempunyai konsentrasi yang singkat. Anak usia dini mempunyai daya konsentrasi yang tidak dapat terlalu lama (Sujiono, 2009)

\section{e. Field Test}

Pada tahap field test mengujicobakan games pembelajaran selama $6 x$ pertemuan dengan subjek yaitu 18 anak di kelas B.2. Pada tahap ini lembar observasi diberikan kepada 6 observer ketika proses pembelajaran berlangsung, tujuan observasi untuk melihat efek potensial yang terjadi dalam proses pembelajaran untuk mendukung curiosity anak tentang matematika awal. Hasil dari lembar observasi didapati rata-rata anak memiliki kategori curiosity yang sangat tinggi dalam mengexplore games pembelajaran senilai $85,1 \%$, hal ini dikarenakan anak mempunyai rasa ingin tahu akan games pembelajaran merupakan sesuatu yang baru, hal ini sejalan dengan pendapat teori bahwa curiosity dapat muncul karena adanya keterbaruan, hal ini juga sejalan dengan pendapat Mendel dalam (Jirout \& Klahr, 2012) dan hal ini memotivasi perilaku ingin tahu akan pembelajaran matematika awal dikarenakan keinginan anak yang sangat tinggi untuk mengexplore games yang ada di android (Reio, 2010; Shiau \& Wu, 2013).

Pada indikator discover, rata-rata anak memiliki kategori curiosity tinggi sebesar 79,6\%, dilihat dari ujicoba yang ada dilapangan, rata-rata anak masih memerlukan bimbingan oleh guru dan bertanya pada teman yang telah mengerjakan, meskipun demikian, anak-anak tetap dapat menyelesaikan persoalan permainan dengan antusiasnya bermain sambil belajar, hal ini didukung oleh teori (Aslant, 2011; Cantor \& N.Cantor, 1964) bahwa curiosity adalah motivasi untuk menemukan dan mencari informasi untuk menyelesaikan persoalan dari tidak tahu menjadi tahu. Indikator selanjutnya yaitu imajinasi, hasil ratarata sebesar $87 \%$, dengan kategori sangat tinggi, anak dapat mengimajinasikan konteks yang ada pada games tersebut dengan kegiatan yang biasanya mereka lakukan seharihari, anak dapat mengembangkan imajinasinya dengan kata-kata untuk belajar mengenalkan matematika awal dengan konteks sehari-hari yang dekat dengan lingkungan anak (Shah et al., 2018). 
Indikator terakhir adalah bertanya, pada indikator ini semua anak berpotensi bertanya dengan rata -rata $96,2 \%$, anak sealalu ingin tahu akan cara menjawab soal dan berkeinginan untuk mendapatkan reward yang ada di permainan, hal ini membangkitkan semangat anak untuk terus menyelesaikan persoalan yang ada di games pembelajaran, sejalan dengan ciri dari curiosity yaitu anak sering bertanya akan sesuatu hal yang dianggapnya menarik dan menantang (Binson, 2009; Kemendiknas, 2010; Kurniawan, 2013). Dari perhitungan hasil observasi menunjukkan bahwa games pembelajaran berbasis android yang telah dikembangkan oleh peneliti memiliki efek potensial untuk mendukung curiosity anak dalam pembelajaran matematika awal. Sejalan dengan penelitian terdahulu yang telah dilakukan (Senisi, 2012; Zaranis, 2016, 2017; Apsari \& Rizki, 2018) keterkaitan yang positif antara penggunaan ICT dan pengembangan pemikiran matematika, serta memberikan pengaruh positif pada ranah kognitif. Selain itu pendapat ini didukung juga oleh (Clements et al., 2016; Kumari, 2016) penelitiannya mengungkapkan bahwa konsep matematika seperti bilangan, berhitung, geometri dan pengelompokkan dapat dipahami dengan mudah ketika anak menggunakan permainan teknologi dengan bantuan guru.

Games pembelajaran berbasis android yang dikembangkan dapat membantu anak usia dini dalam pengenalan matematika awal. Karena anak dapat dengan mudah mempelajari dan mengenal angka, ukuran, bentuk dan memotivasinya ingin tahu dan menyelesaikan persoalan yang ada di dalam permainan. Games pembelajaran berbasis android ini memberikan kontribusi bagi rasa ingin tahu anak dalam pembelajaran awal matematika, karena menurut penelitian karakteristik anak usia dini selalu ingin bermain dan senang akan hal baru dan ingin mencoba sesuatu hal yang menarik perhatian dan hal ini membuat motivasi baru untuk selalu ingin tahu dan terus mencoba dalam menyelesaikan permasalahan dan mengenal matematika awal (Loewenstein, 1994; Rahayu et al., 2019c; Shah et al., 2018)

Untuk pembelajaran dengan menggunakan gadget berikan rule atau aturan mengenai penggunaan gadget untuk memberikan informasi dan belajar bersama. Meskipun belajar bisa didapat dengan bermain games menggunakan android, namun anak harus mengetahui makna pembelajaran menggunakan media android karena tidak dapat dielakkan dan didukung oleh banyak penelitian yang membuktikan bahwa anak usia dini sangat dekat dengan gadget (Nisa', 2020; Rahayu et al., 2019b; Zaini \& Soenarto, 2019)

Penelitian ini menambah kontribusi pada pedagogy pembelajaran matematika awal pada anak usia dini untuk mendukung rasa ingin tahu anak dengan menggunakan media ICT yaitu permainan pembelajaran di HP Android berbasis PMRI dengan konteks pempek sebagai starting point pembelajaran, karena pempek adalah makanan khas daerah yang mudah ditemukan di kehidupan sehari-hari dan dapat dihubungkan dengan berbagai macam sub tema yang ada di tiap bagian materi matematika awal anak usia dini. Media ICT yang telah dibuat dapat membantu siswa dalam pembelajaran matematika awal untuk mendukung rasa ingin tahu anak dan membantu guru sebagai media yang memudahkan dalam memberikan materi pembelajaran pada anak. 
DOI: https://doi.org/10.24127/ajpm.v10i1.3546

\section{KESIMPULAN DAN SARAN}

Berdasarkan penelitian yang telah dilakukan pada produk games pembelajaran matematika awal dengan berbasis android maka dapat disimpulkan games pembelajaran yang telah dikembangkan dinyatakan valid oleh para ahli yang diuji kan pada 3 aspek, materi, media dan praktisi dan layak serta praktis digunakan. Diujicobakan one-to-one pada 3 orang anak yang berbeda kemampuan serta pada small group pada 5 anak dan memiliki efek potensial untuk mendukung curiosity dalam pembelajaran pengenalan matematika awal.

Saran untuk langkah penelitian selanjutnya yang berhubungan dengan penelitian ini, disarankan untuk mengukur rasa ingin tahu anak, berikan anak stimulus seluas-luasnya dan ukur dengan berbagai indikator lainnya. Pendesainan selanjutnya berikan lebih banyak lagi subtema yang dapat dikaitkan dengan tema yang ada di pembelajaran usia dini.

\section{DAFTAR PUSTAKA}

Apsari, P. N., \& Rizki, S. (2018). Media Pembelajaran Matematika Berbasis Android Pada Materi Program Linear. AKSIOMA: Jurnal Program Studi Pendidikan Matematika, 7(1), 161-170. https://doi.org/10.24127/ajpm.v7i1. 1357.

Aslant. (2011). Handbook of Moral and Character Education, Edt. Larry P. Nucci and Darcia Narvaez. International Journal of Instruction, 4(2), 211-214

Binson, B. (2009). Curiosity-Based Learning (CBL) Program. Online Submission, 6(12), 13-22.

Bozick, R., Owings, J. A., Frye, D.,
Baroody, A. J., Burchinal, M., Carver, S. M., Jordan, N. C., McDowell, J., Lortie-Forgues, H., Tian, J., Siegler, R. S., Powell, S. R., Herbert, M. A., Cohen, J. A., Casa, T. M., \& Firmender, J. M. (2017). Mathematics Coursetaking and Achievement at the End of High School: Evidence From the Education Longitudinal Study of 2002. Journal of Writing Research, 2002, 165.

Cantor, joan H., \& N.Cantor, G. (1964). Child Development and Neuroscience Published by: Wiley on behalf of the Society for Research in Child Development Stable. Child Development, 35(5), 119-128.

Chonchaiya, W., \& Pruksananonda, C. (2008). Television viewing associates with delayed language development. Acta Paediatrica, International Journal of Paediatrics, 97(7), 977-982. https://doi.org/10.1111/j.16512227.2008.00831.x

Chusna, P. A. (2017). Pengaruh Media Gadget Pada Perkembangan Karakter Anak. Dinamika Penelitian: Media Komunikasi Sosial Keagamaan, 17(2), 315$330 . \quad$ https://eresources.perpusnas.go.id:2093/doi /abs/10.1142/S0192415X20500500

Clements, D H, \& Group, C. W. (2004). Part one: Major themes and recommendations. Engaging Young Children in Mathematics: Standards for Early Childhood Mathematics Education, April.

Clements, D. H., \& Sarama, J. (2007). Effects of a preschool mathematics curriculum: Summative research on the Building Blocks project. Journal for Research in 
DOI: https://doi.org/10.24127/ajpm.v10i1.3546

\section{Mathematics Education, 38(2), 136-163.}

Clements, D. H., \& Sarama, J. (2011). Early childhood mathematics intervention. Science, 333(6045), 968-970.

https://doi.org/10.1126/science.120 4537

Clements, D. H., Wilson, D. C., \& Sarama, J. (2004). Young Children's Composition of Geometric Figures: A Learning Trajectory. Mathematical Thinking and Learning, 6(2), 163-184. https://doi.org/10.1207/s15327833 mt10602_5

Clements, D. H, Sarama, J., Clements, D. H., \& Sarama, J. (2016). Blocks Project Linked references are available on JSTOR for this article: Curriculum: Building Blocks Project. Journal for Research in Mathematics Education, 38(2), 136-163.

De Lange, J. (2019). Curious Minds: Serious Play. Theory and Practice: An Interface or A Great Divide?, 130-135.

https://doi.org/10.37626/ga978395 9871129.0.26

Dwyer, J. (2007). Computer-based learning in a primary school: Differences between the early and later years of primary schooling. Asia-Pacific Journal of Teacher Education, 35(1), 89-103. https://doi.org/10.1080/135986606 01111307

Fisher, T., Denning, T., Higgins, C., \& Loveless, A. (2012). Teachers' knowing how to use technology: Exploring a conceptual framework for purposeful learning activity. Curriculum Journal, 23(3), 307325. https://doi.org/10.1080/09585176.2 012.703492

Jirout, J., \& Klahr, D. (2012). Children's scientific curiosity: In search of an operational definition of an elusive concept. Developmental Review, 32(2), 125-160.

https://doi.org/10.1016/j.dr.2012.0 4.002

Kashdan, T. B., Stiksma, M. C., Disabato, D. D., McKnight, P. E., Bekier, J., \& Kaji, J. (2018). FiveDimensional Curiosity Scale (5DC). 73, 21-22.

Kemendiknas. (2010). Pendidikan Karakter di Sekolah Menengah Pertama. Kemendiknas.

Korth, B. B., Erickson, L., \& Hall, K. M. (2009). Defining Teacher Educator Through the Eyes of Classroom Teachers. The Professional Educator, 33(1), 112.

Kumari, A. (2016). Learning Shaped By Ict in Early Childhood Care and Education : Indian Context. JUNE 2014.

Kurniawan. (2013). Pengaruh kompetensi pedagogik, dan kompetensi professional Guru. UPI Pustaka Belajar.

Laorenco, orlando m. (2015). Piaget, Jean. 2, 623-628.

Latif, M. (2013). Pendidikan Anak Usia Dini. Kencana Prenada Media Group.

Lee, Y. (2009). Pre-K Children's Interaction with Educational Software Programs; An Observation of Capabilities and Levels of Engagement. Journal of Educational Multimedia and Hypermedia, 18(3), 289-309. 
DOI: https://doi.org/10.24127/ajpm.v10i1.3546

https://www.learntechlib.org/prima $\mathrm{ry} / \mathrm{p} / 28310 /$.

Loewenstein, G. (1994). Loewenstein, 1994. Psychological Bulletin, 116(1), 75-98.

Mashrah, H. T. (2017). The Impact of Adopting and Using Technology by Children. Journal of Education and Learning (EduLearn), 11(1), 35.

https://doi.org/10.11591/edulearn.v $11 \mathrm{i} 1.5588$

Musrikah. (2017). pengajaran matematika pada anak usia dini. Martabat (Jurnal Perempuan Dan Anak), 1(1), 154-174. https://doi.org/10.21274/martabat.2 017.1.1.153-174

Mustari, M. (2011). Refleksi Untuk Pendidikan Karakter. 1-13.

Nabawy, G. El, Moawad, A., Gad, G., \& Ebrahem, S. (2016). The Relationship between use of Technology and ParentAdolescents Social Relationship. Journal of Education and Practice, 7(14), 168-178.

Nisa', L. (2020). Pemanfaatan Teknologi Dalam Pendidikan Anak Usia Dini. ThufuLA: Jurnal Inovasi Pendidikan Guru Raudhatul Athfal, 8(1), 001. https://doi.org/10.21043/thufula.v8 i1.6283

Perry, B., \& Dockett, S. (2015). Young children's access to powerful mathematical ideas. In Handbook of International Research in Mathematics Education. https://doi.org/10.4324/978020393 0236.ch5

Pluck, G., \& Johnson, H. (2011). Stimulating Curiosity To Enhance Learning. Education Sciences and Psychology, 2, 24-31.
Raharja, S., Wibhawa, M. R., \& Lukas, S. (2018). Mengukur rasa ingin tahu siswa. POLYGLOT, Jurnal Ilmiah, 14(2), 151.

Rahayu, C., Putri, R. I. I., Zulkardi, \& Hartono, Y. (2019a). ICT on mathematics learning process at Pagaralam elementary school. Journal of Physics: Conference Series.

https://doi.org/10.1088/17426596/1188/1/012069

Rahayu, C., Putri, R. I. I., Zulkardi, \& Hartono, Y. (2019b). On curiosity to introduce mathematics in early childhood. Journal of Physics: Conference Series. https://doi.org/10.1088/17426596/1166/1/012032

Rahayu, C., Putri, R. I. I., Zulkardi, \& Hartono, Y. (2019c). Using mathematics education game based ICT: Why children like to play game? Journal of Physics: Conference Series. https://doi.org/10.1088/17426596/1315/1/012062

Reio, T. (2010). Adolescent education: A reader. Peter Lang.

Sarilawati, D. (2012). Percaya Diri, Keingintahuan, Dan Berjiwa Wirausaha: Tiga Karakter Penting Bagi Peserta Didik. Jurnal Pendidikan Karakter, O(2), 213224. https://doi.org/10.21831/jpk.v0i2.1 305

Senisi, E. B. (2012). Finding the Education in Educational Technology with Early Learners. YC Young Children, 67(3), 14-24.

Shah, P. E., Weeks, H. M., Richards, B., \& Kaciroti, N. (2018). Early childhood curiosity and kindergarten reading and math 
DOI: https://doi.org/10.24127/ajpm.v10i1.3546

academic achievement. Pediatric Research, 84(3), 380-386. https://doi.org/10.1038/s41390018-0039-3

Shiau, W. L., \& Wu, H. C. (2013). Using curiosity and group-buying navigation to explore the influence of perceived hedonic value, attitude, and group-buying behavioral intention. Journal of Software, 8(9), 2169-2176. https://doi.org/10.4304/jsw.8.9.216 9-2176

Siraj-Blatchford, John; Whitebread, D. (2003). Supporting Information and Communications Technology in the Early Years. Supporting Early Learning Series. Open University Press.

Sudjana, N. (2009). Penilaian Hasil Proses Belajar mengajar. PT. Remaja Rosdakarya.

Suhana, M. (2018). Influence of Gadget Usage on Children's SocialEmotional Development. 169(Icece 2017), 224-227. https://doi.org/10.2991/icece17.2018 .58

Sujiono, Y. N. (2009). Konsep Dasar Pendidikan Anak Usia Dini. PT.Indeks.

Sukardjo. (2012). Kumpulan Materi Evaluasi Pembelajaran. UNY Yogyakarta.

Sum, T. A., \& Taran, E. G. M. (2020). Kompetensi Pedagogik Guru PAUD dalam Perencanaan dan Pelaksanaan Pembelajaran. Jurnal Obsesi: Jurnal Pendidikan Anak Usia Dini, 4(2), 543. https://doi.org/10.31004/obsesi.v4i 2.287
Tessmer, M. (1993). Planning and Conducting Formative Evaluations (1st ed.). Kogan Page. https://doi.org/https://doi.org/10.43 24/9780203061978

Trundle, K. C., Mollohan, K., \& Smith, M. M. (2013). Plants, Alike and Different. Science and Children, 50(6), 52-57.

Zaini, M., \& Soenarto, S. (2019). Persepsi Orangtua Terhadap Hadirnya Era Teknologi Digital di Kalangan Anak Usia Dini. Jurnal Obsesi: Jurnal Pendidikan Anak Usia Dini, 3(1), 254. https://doi.org/10.31004/obsesi.v3i 1.127

Zaranis, N. (2016). The use of ICT in kindergarten for teaching addition based on realistic mathematics education. Education and Information Technologies, 21(3), 589-606.

https://doi.org/10.1007/s10639014-9342-8

Zaranis, N. (2017). Does the use of Information and Communication Technology through the use of Realistic Mathematics Education help kindergarten students to enhance their effectiveness in addition and subtraction? Preschool and Primary Education, 5(1), 46. https://doi.org/10.12681/ppej.9058 